\title{
Isolation of Bacillus subtilis CK-2 Hydrolysing Various Organic Materials
}

\author{
Chul-Ho Kim* and Sang-Hyup Lee
}

\section{Department of Phamaceutical Engineering Gyeongnam National University of Science and Techndogy, Jinju 660-758, Korea}

Received September 29, 2011 /Revised November 10, 2011 /Accepted December 6, 2011

\begin{abstract}
A bacterium hydrolysing various organic materials including cellulose, protein, starch and lipid was isolated. The isolate was identified as Bacillus subtilis, and named Bacillus subtilis CK-2 in this paper. This bacterium showed optimal growth at $40 \sim 45{ }^{\circ} \mathrm{C}, \mathrm{pH} 6 \sim 9$, and $0 \sim 3 \%$ of $\mathrm{NaCl}$. B. subtilis CK-2 seemed to synthesis highly active autolysin. The hydrolytic enzymes produced by $B$. subtilis CK-2 were primary enzymes because extracellular enzyme activities varied similarly to the growth curve. The hydrolytic enzymes seemed to be stable at basic $\mathrm{pH}$ conditions. From these results, B. subtilis CK-2 was found to bea useful bacterial agent for composting, or for use in feed-production waste in agriculture, fishery, forest materials, livestock farming, and food.
\end{abstract}

Key words : Bacillus subtilis, cellulase, protease, amylase, lipase

\section{서 론}

생태계의 구성 요인으로서의 세균은 유기물을 분해하여 물 질의 순환에 큰 기여를 할 뿐만 아니라, 이들이 분비하는 여러 가지 유기물 분해효소들은 산업적으로도 매우 중요하게 활용 되고 있다.

섬유소(cellulose)는 지구상에서 가장 풍부한 유기물로서 인간은 수백년 동안 이 물질을 에너지원이나 사료 등으로 이용하였다. 섬유소를 이용하기 위해서는 먼저 섬유소분해 효소에 의한 가수분해가 선행되어야 하는데, 이는 균류나 세균 등 미생물에 의해 생성된다[18]. 섬유소분해효소는 섬 유소가 존재할 때만 합성되는 유도성 효소로서[12], 섬유소 를 완전히 분해하기 위해서는 endoglucanase와 exocellobiohydrolase, 그리고 $\beta$-glucosidase 등 서로 다른 효소를 필요 로 한다[23]. 섬유소분해효소는 광범위한 분야에서 많은 관 심을 끌어왔다. 무엇보다 큰 관심은 산업적인 측면에서 가 졌는데, 섬유광택제나 세제 등의 개발에 많이 이용되었고 [4], 포도당이나 알코올, 단백질 등의 생산에 대한 연구도 많 이 이루어졌다[6]. 최근에는 산업 부산물 또는 음식물 폐기 물의 재활용 차원에서 버섯부산물이나 음식물 쓰레기의 퇴 비화 또는 사료화를 위한 섬유소 분해 미생물에 대한 연구 가 많이 이루어지고 있다[1,16].

녹말은 식물세포 속에 다량 함유된 유기중합체로서 생태계 내에서 중요한 재활용 가능한 자원이다. 근래에 여러 산업 분 야에서 미생물을 이용하여 경제성이 있는 제품을 생산하기 위한 노력이 많이 이루어지고 있는데, 그 중에서도 Bacillus $\mathrm{sp}$.는 그람 양성 세균으로서 다양한 효소를 합성하여 세포 외

\section{*Corresponding author}

Tel : +82-55-751-3395, Fax : +82-55-751-3399

E-mail : chkim@gntech.ac.kr
부로 분비하는 특성이 있어 여러 분야에서 응용되고 있는 세 균이다[8]. 아밀라제 (amylase)는 녹말을 분해하는 효소로서 섬 유산업, 제과 - 제빵업, 제지업, 주류업 등에서 광범위하게 이 용되는 효소로서 많은 종류의 미생물에 의해 합성된다[5]. 최 근에는 동물 사료에도 cellulase나 protease 등과 더불어 많이 이용되고 있다[10]. Bacillus sp.는 아밀라제를 생산하는 대표적 인 세균 중 하나로서 현재 다양한 산업 분야에서 활동되고 있다[13].

단백질 분해효소는 산업적으로 이용되는 효소들 중에서도 가장 중요한 것으로서 전체 효소 시장의 $60 \%$ 를 차지하고 있으 며[20], 이들 효소는 대부분 세균에 의해 생산되고, 농업, 피혁, 식품, 의학, 폐기물 처리 등의 산업 분야에서 다양하게 이용된 다[17].

지방분해효소는 triacylglycerol을 가수분해하는 효소로서 지방 가공 공정이나 세제, 식품 가공 공정, 화공 및 제약 합성, 제지 공업, 화장품 제조 공정 등 다양한 분야에 이용되고 있으 며[19], 지방성 폐기물과 polyurethane의 분해 촉진제로 이용 되기도 한다[21]. 본 연구에서는 음식물이나 축산 폐기물 처리, 사료 생산 등의 과정에 활용할 수 있는 미생물 자원을 확보하 기 위하여 섬유소, 단백질, 지질, 녹말 등의 다양한 유기화합물 을 분해할 수 있는 세균을 분리하여 그 특징을 확인하고자 하였다.

\section{재료 및 방법}

\section{유기물 분해세균의 분리}

다양한 유기물을 분해할 수 있는 세균을 분리하기 위해 먼저 섬유소 분해능을 갖는 세균을 1 차 분리하였다. 분리원은 우리 나라 전통음식인 김치와 된장, 청국장 등 식용 가능한 재료를 이용하였다. 적당히 희석한 시료를 CMC (Carboxymethyl cel- 
lulose, Difco) $5 \mathrm{~g} / 1$ 을 포함하는 3\% NaCl TSB 한천평반배지 (Tryptic soy broth $3 \mathrm{~g}, \mathrm{NaCl} 30 \mathrm{~g}$, agar $18 \mathrm{~g} / \mathrm{l}$ )에 도말하여 $30^{\circ} \mathrm{C}$ 배양기에서 2 일간 배양한 후 $0.1 \%$ congo red 염색약으로 염색하여 콜로니 주위에 투명환을 형성하는 균주를 선별하였 다[22].

\section{분리균주의 다양한 유기 중합체 분해능 확인}

섬유소 분해능이 있는 균주를 대상으로 하여 지질, 단백 질, 녹말의 분해능을 확인하였다. 이를 위하여 섬유소 분해 활성을 나타내는 350 여 개의 콜로니를 선별하여 상기의 각 각의 유기물이 첨가된 $\mathrm{TSB}$ 한천평판배지에 접종하여 $30^{\circ} \mathrm{C}$ 배양기에서 2 일간 배양한 후 지질 분해능과 단백질 분해능 은 직접 눈으로 확인하였고, 녹말 분해능은 요오드 용액을 처리하여 콜로니 주위에 투명환을 형성하는 균주를 최종 선 별하였다.

\section{분리균주의 생장 특성 및 동정}

분리균주의 최적 생장 조건 $(\mathrm{pH}$, 온도, 염도)은 서로 다른 조건에서 배양하면서 일정시간 간격으로 시료를 취하여 660 $\mathrm{nm}$ 에서의 흡광도를 측정하여 확인하였다. 분리균주는 생장 특성과 이화학적 특성, 그리고 당 이용능 시험인 $\mathrm{API} 50 \mathrm{CHB}$ kit (BioMerieux, France) 결과 등을 근거로 하여 Bergey's Manual of Systematic Bacteriology에 의하여 동정하였으며, $16 \mathrm{~S}$ rRNA 염기서열 분석을 통한 동정을 병행하였다.

\section{효소 활성 측정}

분해효소의 활성은 다음과 같이 흡광도법으로 측정하였다. 섬유소분해효소의 활성은 3, 5-dinitrosalicylic acid (DNS) 법 에 의거하여 $\mathrm{CMC}$ 로부터 유리되는 환원당의 농도로 측정하였 다[2]. 녹말분해효소의 활성은 $\mathrm{DNS}$ 법에 의거하여 녹말이 분 해될 때 유리되는 환원당의 농도로 측정하였다[15]. 단백질 분 해효소의 활성은 azocasein으로부터 유리되는 peptides의 양 을 측정하였다[9].

\section{분리세균의 생장에 따른 세포외 효소 활성 변화}

분리균주를 NB (Nutrient broth, Difco) 배지에 접종하여 $180 \mathrm{rpm}, 35^{\circ} \mathrm{C}$ 배양기에서 배양하면서 1 시간 간격으로 시료를 채취하여 $\mathrm{pH}$ 변화와 세포외 섬유소분해효소의 활성을 측정하 였다. 먼저 시료를 $6,000 \times g$ 에서 10 분간 원심분리한 후 상등액 을 구경 $0.22 \mu \mathrm{m}$ 의 막여과지로 여과한 용액을 이용하여 효소 활성을 측정하였다[7].

\section{결과 및 고찰}

\section{유기물 분해세균의 분리}

먼저 $\mathrm{CMC}$ 가 첨가된 $3 \% \mathrm{NaCl} \mathrm{TSB}$ 한천평반배지 상에서 섬유소 분해능을 갖는 균주를 1 차 선별하고, 이들 균주를 단백 질, 지질, 녹말이 첨가된 TSB 한천평판배지에 배양하여 모든 유기물에 대한 분해활성을 갖는 균주를 분리하였다. 분리균주
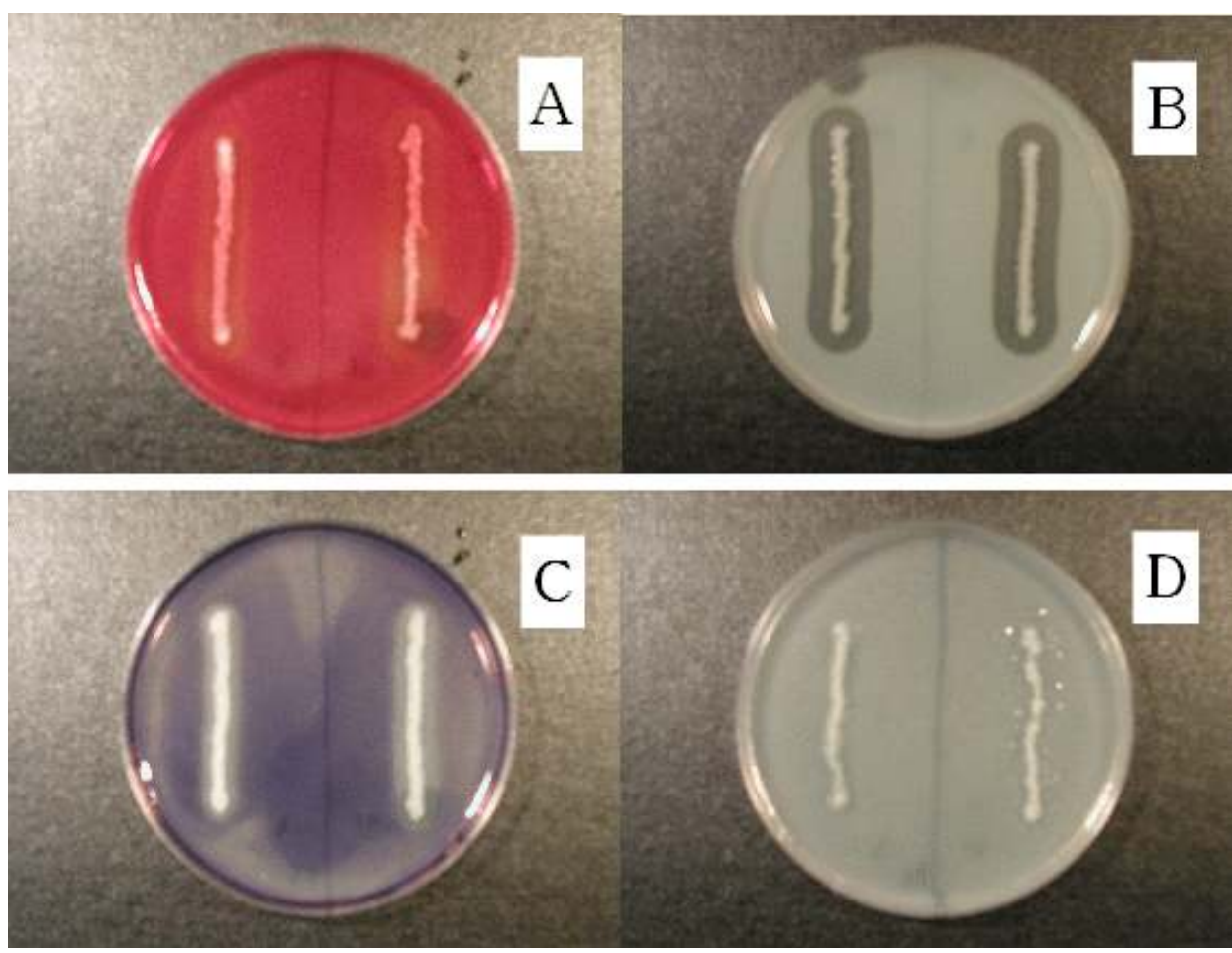

Fig. 1. Photographs showing extracellular hydrolytic enzyme activities against cellulose (A), protein (B), starch (C), and lipid (D). 
는 Fig. 1 에서 보는 바와 같이 각 유기 중합물질에 대한 분해활 성을 보였다. 이와 같이 분리세균이 대표적 고분자 유기물질 들 모두에 대해 분해활성을 갖는다는 것은 향후 이 세균의 응용에 있어 큰 의미를 가진다.

\section{분리균주의 생장 특성 및 동정}

분리균주는 $40 \sim 45^{\circ} \mathrm{C}$ 범위의 온도에서 잘 자랐으며, $\mathrm{pH}$ 6 9 의 넓은 범위의 수소이온농도에서 잘 자랐고, TSB 배지에 $\mathrm{NaCl} 0 \sim 3 \%$ 를 첨가한 배지에서 유사한 생장을 보였다. TSB 배지에 $\mathrm{NaCl} 3 \%$ 이상을 첨가한 배지에서는 생장이 급격히 감소하는 양상을 나타내었다.

분리균주는 Table 1에서 나타낸 것과 같은 특성을 가지며, Bergey's Manual of Systematic Bacteriology과 16S rRNA 염 기서열 분석 결과 Bacillus subtilis로 분류되었고, Bacillus subtilis CK-2로 명명하였다.

\section{분리세균의 생장에 따른 세포외 효소 활성 변화}

분리세균을 TSB 배지에서 배양하면서 분리균주의 생장곡 선과 배지의 $\mathrm{pH}$ 변화, 그리고 세포외 유기물분해효소의 활성
도 변화를 측정한 결과 Fig. 2에 나타낸 바와 같았다. 분리세균 은 배양 후 2 3시간부터 급격하게 생장하여 7시간 경과 후 최고 생장을 보이다가 이후에는 급격하게 사멸하는 양상을 보였다. 이러한 생장 특성은 일부 유기물 분해활성이 높은 균 주에서 볼 수 있는 것으로, 세균이 합성하는 다양한 가수분해 효소 중 자가분해효소(autolysin)의 작용에 의한 것으로 생각 한다[11]. 세균의 생장에 따라 배지의 $\mathrm{pH}$ 는 배양 초기에는 점 차 감소하여 배양 후 3시간 경에 $\mathrm{pH}$ 7.1을 나타낸 이후에는 점차 증가하여 배양 12 시간 후에는 $\mathrm{pH} 8.7$ 정도의 높은 염기성 을 나타내었다. 세포외 유기물 분해효소의 활성은 배양 초기 에는 세균의 생장곡선과 거의 비슷한 양상을 나타내며 상승하 다가 세균의 개체군 생장이 멈추는 정체기에 접어들면서 최고 의 활성을 나타낸 후 거의 일정한 수준을 유지하였다. 섬유소 분해효소와 녹말 분해효소에 비해 단백질 분해효소는 세균 배양 과정에서 약간 빠른 시기부터 세포외 효소 활성을 나타 내는 것을 알 수 있었다. 이러한 결과로부터 Bacillus subtilis CK-2가 분비하는 가수분해효소가 1 차 대사산물이라는 것을 알 수 있으며, $\mathrm{pH} 8.7$ 정도의 높은 $\mathrm{pH}$ 조건에서도 활성을 유지 한다는 점에서 염기성 조건에서의 안정성을 가지는 것으로

Table 1. Characteristics of isolate

\begin{tabular}{|c|c|c|c|}
\hline Items & Results & Items & Results \\
\hline Shape & Rod & Amygdalin & - \\
\hline Endospore formation & + & Arbutin & + \\
\hline Motility & + & Esculin & + \\
\hline Gram stain & + & Salicin & - \\
\hline Oxygen demand & Facultative & Cellobiose & + \\
\hline Catalase & + & Maltose & + \\
\hline Glycerol & + & Lactose & - \\
\hline Erythriol & - & Melibiose & - \\
\hline D-Arabinose & - & Sucrose & + \\
\hline L-Arabinose & + & Trehalose & + \\
\hline Ribose & + & Inulin & + \\
\hline D-Xylose & + & Melezitose & - \\
\hline L-Xylose & - & Raffinose & - \\
\hline Adonitol & - & Starch & + \\
\hline$\beta$-Methyl-D-xyloside & - & Glycogen & + \\
\hline Galactose & - & Xylitol & - \\
\hline D-Glucose & + & Gentiobiose & + \\
\hline D-Fructose & + & D-Turanose & + \\
\hline D-Mannose & + & D-Lyxose & - \\
\hline L-Sorbose & - & D-Tagatose & - \\
\hline Rhamnose & - & D-Fucose & - \\
\hline Dulcitol & - & L-Fucose & - \\
\hline Inositol & + & D-Arabitol & - \\
\hline Mannitol & + & L-Arabitol & - \\
\hline Sorbitol & + & Gluconate & - \\
\hline a-Methyl-D-mannoside & - & 2-keto-gluconate & - \\
\hline a-Methyl-D-glucoside & + & 5-keto-gluconate & - \\
\hline N-Acetyl glucosamine & + & & \\
\hline
\end{tabular}



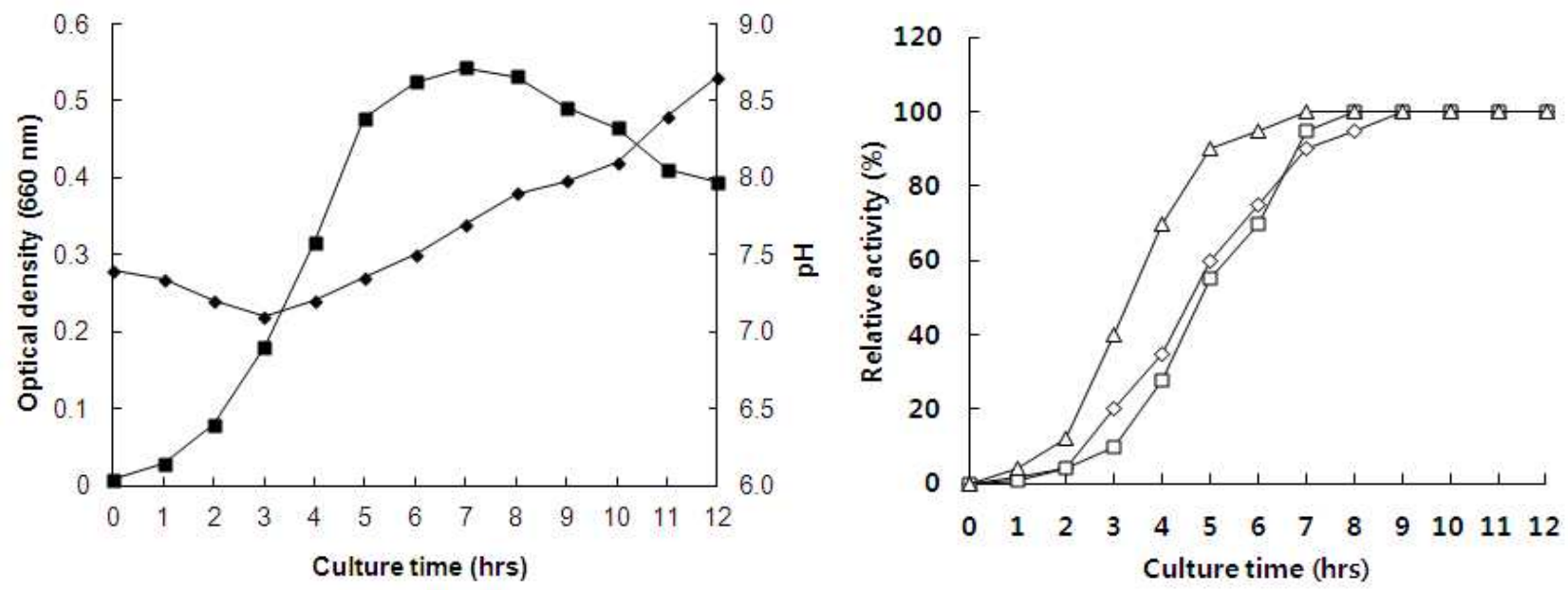

Fig. 2. Growth curve $(\boldsymbol{\square}), \mathrm{pH}$ variation of culture medium , and variation of extracellular enzyme activities of Bacillus subtilis CK-2. $\diamond$ : amylase, $\square$ : cellulase, $\triangle$ : protease.

생각된다.

이상의 결과로부터 본 연구에서 분리한 Bacillus subtilis CK-2는 섬유소, 지질, 단백질, 녹말 등 다양한 유기 중합체를 분해하는 것을 확인할 수 있었다. 지금까지 각각의 물질에 대 한 분해 세균에 대한 연구는 활발하게 이루어졌지만, B.subtilis CK-2와 같이 다양한 유기물을 분해할 수 있는 세균에 대 한 연구는 거의 이루어지지 않았다. 이와 같은 특징은 B.subtilis CK-2가 통기성의 내생포자 형성균으로서 $3 \%$ 정도의 염분 에서도 왕성한 생장이 가능하다는 점 등과 더불어 각종 유기 성 폐기물 처리나 세제 개발 등에 응용 가능할 것이며, 또한 분리원이 우리가 널리 식용으로 이용하는 된장이라는 점을 감안하면 안전성을 확보할 수 있어 사료 생산 공정에도 활용 이 가능할 것으로 생각된다.

\section{감사의 글}

본 논문은 2009년도 경남과학기술대학교 기성회 연구비의 지원으로 수행한 연구 결과입니다.

\section{References}

1. Ariffin, H., N. Abdullah, M. S. U. Kalsom, Y. Shirai, and M. A. Hassan. 2006. Production and characterisation of cellulase by Bacillus pumilus EB3. International J. Engineering and Technology 3, 47-53.

2. Bailey, M. J., P. Biely, and K. Poutanen. 1992. Inter-laboratory testing of methods for assay of xylanase activity. J. Biotechnol. 23, 257-270.

3. Bhat, M. K. and S. Bhat, 1997. Celllose degrading enzymes and their potential industrial applications. Biotechnology Advences 15, 583-620.

4. Coral, G., B. Arikan, M. N. Ünaldi, and H. Güvenmez. 2002.
Some properties of crude carboxymethyl cellulase of Aspergillus niger Z10 wild-type strain. Turk J. Biol. 26, 209-213.

5. Emtiazi, G. and I. Nahvi. 2004. Production of thermostable a-amylase and cellulase from Cellulomonas sp.. J. Microbiol. Biotechnol. 14, 1196-1199.

6. Heck, J. X., P. F. Hertz, and M. A. Z. Ayub, 2002. Cellulase and xylanase production by isolated amazon Bacillus strains using soybean industrial residue based solid-state cultivation. Brazil. J. Microbiol. 33, 213-218.

7. Ibrahim, A. S. S. and A. K. El-diwany. 2007. Isolation and identification of new cellulases producing thermophilic bacteria from an Egyptian hot spring and some properties of the crude enzyme. Aust. J. Basic \& Appl. Sci. 1, 473-478.

8. Igarashi, K., Y. Hatada, H. Hagihara, K. Saeki, M. U. T. Takaiwa, K. Arai, K. Ozaki, S. Kawai, T. Kobayashi, and S. Ito. 1998. Enzymatic properties of a novel liquefying a -amylase from an alkalophilic Bacillus isolated and entire nucleotide and ammino acid sequences. Appl. Environ. Microbiol. 64, 3282-3289.

9. Janssen, P. H., K. Peek, H. W. Morgan. 1994. Effect of culture conditions on the production of a extracellular proteinase by Thermus sp. Rt41A. Appl. Microbid. Biotechnd. 41, 400-406.

10. Johansson, T. and P. O. Nyman, 1993. Isoenzymes of lignin peroxidase and manganese peroxidase from the white-rot Basidiomycete Arch Biochem Biophys. 300, 49-56.

11. Kim, C. H., M. H. Leam, and Y. K. Choi, 1997. Isolation of a bacterium that inhibits the growth of Anabaean cylindrica. The Journal of Microbiol. 35, 284-289.

12. Katz, M. and E. T. Reese. 1968. Production of glucose by enzymatic hydrolysis of cellulose. Appl. Microbiol. 16, 419-420.

13. Lee, H. S., Y. W. Ryu, and C. Kim, 1994. Hydrolysis of starch by a-amylase and glucoamylase in supercritical carbon dioxide. J. Microbiol. Biotechnol. 4, 230-232.

14. Masse, L., K. J. Kennedy, and S. P. Chou, 2001. The effect 
of an enzymatic pretreatment on the hydrolysis and size reduction of fat particales in slaughterhouse wastewater. $J$. Chem Technol. Biotechnol. 76, 629-635.

15. Miller, G. L. 1959. Use of dinitrosalicylic acid reagent for determination of reducing sugar. Anal. Chem 31, 426-428.

16. Nakasaki, K. and T. Akiyama. 1988. Effect of seeding on thermophilic composting of household organic waste. J. Ferment. Technol. 66, 37-42.

17. Nascimento, W. C. A. and M. L. L. Martins. 2004. Production and properties of an extracellular protease from thermophilic Bacillus sp.. Braz. J. Microbiol. 35, 91-96.

18. Robson, L. M. and G. H. Chambliss. 1989. Cellulases of bacterial origin enzyme. Microb. Technol. 11, 612-643.

19. Rubin, B. and E. A. Dennis. 1997. Lipases: Part A. Biotechnology Methods in Enzymology, vol. 284. pp. 1-408,
Academic Press, New York.

20. Sigh, J., N. Batra, C. R. Sobti. 2001. Serine alkaline protease from a newly isolated Bacillus sp. SSR1. Proc. Biochem 36, 781-785.

21. Takamoto, T., H. Shirasaka, H. Uyama, S. Kobayashi. 2001. Lipase-catalyzed hydrolytic degradation of polyurethane in organic solvent. Chem Lett. 6, 492-493.

22. Wood, T. M. and K. M. Bhat. 1988. Methods for measuring cellulose activities. Methods Enzymol. 160, 87-112.

23. Yi, J. C., A. B. Sandra, and T. C. Shu, 1999. Production and distribution of endoglucanase, cellobiohydrolase, and $\beta$ -glucosidase components of the cellulolytic system of Volvariella volvacea, the edible straw mushroom. Appl. Environ. Microbiol. 65, 553-559.

\section{초록 : 다양한 유기물을 분해하는 Bacillus subtilis CK-2의 분리}

\section{김철호* $\cdot$ 이상협}

(경남과학기술대학교 제약공학과)

섬유소를 비롯한 단백질, 지질, 녹말을 분해할 수 있는 세균을 된장으로부터 분리하여 동정한 결과 Bacillus subtilis로 분류되었으며, Bacillus subtilis CK-2로 명명하였다. 분리균주는 $40 \sim 45^{\circ} \mathrm{C}$ 의 비교적 넓은 온도 범위와 $\mathrm{pH}$ 6 9의 넓은 $\mathrm{pH}$ 범위, 그리고 $\mathrm{NaCl} \mathrm{0} \mathrm{3 \%} \mathrm{범위에서} \mathrm{잘} \mathrm{자랐으며,} \mathrm{높은} \mathrm{자가분해효소} \mathrm{활성을} \mathrm{갖는} \mathrm{것을} \mathrm{알} \mathrm{수} \mathrm{있었}$ 다. B. subtilis CK-2가 분비하는 가수분해효소들은 대부분 세균의 생장과 거의 비례적으로 세포외 활성을 나타내 는 1차 대사산물로 확인되었다. 이상의 결과로부터 B. subtilis CK-2는 농수임산물 폐기물이나 음식물 폐기물의 퇴비화, 사료 생산 등에 유용하게 이용될 수 있을 것으로 생각한다. 